\title{
Identification of Linkage Between Strategic Group and Performance of Indian Commercial Banks: A Combined Approach using DEA and Co-Plot
}

\author{
Prithwiraj Nath. XLRI Jamshedpur. India. \\ prithwiraj@xlri.ac.in
}
Avinandan Mukherjee. Nanyang Technological University. Singapore Aavinandan@ntu.edu.sg
Manabendranath Pal. Indian Institute of Management Calcutta. India mnp@iimcal.ac.in

\begin{abstract}
This paper explores the linkage between strategic grouping and performance of the Indian banking sector. Strategic grouping and performance were identified using published financial information for all public sector banks. Grouping of Indian public sector banks following comparable financial strategy - with similar asset quality, operational efficiency and profitability - was operationalized using the graphical display method of Co-plot.

From their position in the two dimensional conceptual map, banks with identical financial performance formed strategic groups with significant positive linkage between better groups and their superior financial performance, which showed their inherent homogeneity in business policy decisions. Relative performance of the banks in terms of their efficiency in converting the resources to financial outputs was obtained using data envelopment analysis technique. The measures for potential financial improvements were obtained from the output slacks calculated. Efficient banks were found to be more profitable and their grouping as observed in the efficiency-profitability matrix was found to be identical to the strategic groups obtained using financial ratios.
\end{abstract}

This paper offers a framework to commercial banks to make informed policy decisions about their competitive positioning in the target market, develop long-term strategic focus and identify a benchmark for improving their performance.

Keywords: Co-plot, DEA, Efficiency, Indian banking, Strategic group 


\section{INTRODUCTION}

One of the major areas of macro-economy that has been the subject of focused attention is the efficiency and soundness of the financial sector. Within the broad scope of the financial sector, a stable and properly performing banking system has become the cynosure of the research efforts throughout the world. Particularly in developing countries like India, the focus on the banking sector has heightened due to universalisation of banking operations with continuing deregulation, more competition and technological developments leading to the transformation of a bank from an intermediary between the saver and the borrower to a more customer centric entity. Since, majority of the Indian financial sector assets come from the banking system, it is all the more important to study the efficiency of the Indian commercial banks, understand the potential risks involved and develop policy measures towards a more stable and vibrant banking system (Trend and Progress of Banking in India, 1999-2000).

Efficiency measurement of individual banks is an important research activity carried out by the central bank of the country in order to identify the effects of deregulation, merger, market structure as well as their scale and scope of activity. Indian banks are diverse in their ownership form: publicly owned, privately owned and foreign owned, operating in the country under different regulation norms as set by the Reserve Bank of India, the central bank of the country. In India, the banking sector is dominated by the public sector banks comprising State Bank of India and its group with 8 banks and 19 other nationalized banks. These 27 public banks comprise more than $80 \%$ share in the total assets of all commercial banks. They constitute more than $70 \%$ of the bank branches - a huge distribution network, which privately owned or foreign owned banks cannot match. According to the net profit structure (1998-99), the public banks comprise more than $70 \%$ of the combined figure for all the banks (Trend and progress of banking in India 1998-99). In 1999, Reserve Bank of India came out with the Verma Committee report aimed to understand the causes of the weaknesses and develop a restructuring policy for the weak public sector banks. The committee identified three weak banks and suggested their closure or merger with a better performing bank. Thus, it is all the more necessary for the Indian public sector banks to know their positioning in the strategic groups in the banking industry in this current economic situation. If a poor performer wants to switch over to a better group, it has to understand the strategic dimensions, which make that group more efficient. It also has to comprehend what sort of structural changes in its long-term business policy is required in order to overcome this uncertainty of switching and get the maximum 
advantage out of it. In this study, we have used the financial information on the performance parameters for all the twenty-seven public sector banks for the year 1997-98 in order to understand their strategic grouping.

The concept of strategic group came from Hunt's (1972) classic analysis of competition which defined a strategic group as "a group of firms within an industry that are highly symmetric with respect to cost structure, degree of product differentiation, degree of vertical integration and the degree of product diversification". Porter (1980) defined a strategic group as "the group of firms in an industry following the same or a similar strategy along the strategic dimensions". They are the "group of firms which compete within an industry by deploying similar configuration of resource bundles" (Mehra, 1996). Extensive discussion about strategic groups can be found in McGee and Thomas (1986).

The concept of strategic groups has been used in marketing and strategy literature to identify industry pattern and its linkage with firm performance. Proper identification of strategic groups helps the firms to insulate them not only from the new entrants to the industry but also from firms belonging to other strategic groups in the same industry (Porter, 1979). Zineldin (1996) discusses strategic issues related to bank positioning. He argues that since no bank can offer all products/services and be the preferred bank for all customers, each bank must examine its strengths and opportunities and choose a competitive position for itself in the marketplace. Thus, we have some banks competing in terms of deposit base, some on loans outstanding base and some in terms of assets. This leads to strategic grouping. Mehra (1996) applied the concept of strategic group to U.S. banking industry and obtained a relationship between resource endowments and performance. The relationship between strategic groups and firm performance has been documented in Cool and Schendel (1987), McGee and Thomas (1986). Although, the relationship has been inconclusive in previous studies (Fiegenbaum and Thomas, 1990 and Lewis and Thomas, 1990), it would be of extreme importance to see how the different strategic groups of firms differ in their overall performance in terms of efficiency in converting their resources into outputs and how profitability of firms vary with their efficiency.

Day, Lewin and Li (1995) gave an extensive survey of different techniques like inspection, clustering, discriminant analysis, factor analysis and data envelopment analysis (DEA) which have been used by researchers to identify strategic groups and leaders within each group. Efficiency (technical) measurement in banking means how a bank is able to convert its resources into transaction 
generating activities. Apart from the simple financial ratio method, different parametric methods like stochastic frontier approach developed by Aigner et al. (1977) and used in banking efficiency measurement (Giokas, 1991; Bhattacharya, 1997) and non-parametric methods like Data Envelopment Analysis (DEA) originally developed by Charnes, Cooper, Rhodes (1978) and used extensively in benchmarking efficiency in the banking sector (Oral and Yolalan, 1990; Seiford and Zhu, 1999) have been used to measure banking efficiency. Berger and Humphrey (1997) provide an extensive account of 130 studies that applied different frontier efficiency analysis methods to financial institutions in 21 countries.

We have three broad research questions in this study:

(1) Whether any strategic groupings for the Indian banking sector can be identified from their financial performance variables

(2) Does performance of the banks vary across the different strategic groups

(3) How efficiency of banks in different strategic groups is linked to their profitability

The objective of this paper is to identify strategic grouping of the Indian public sector banks using some key financial ratios, which signifies the policy decisions for their long-term business strategy. We want to measure the performance of these banks by their overall technical efficiency (ability to achieve maximum financial output from the existing resources) and how profitability differs among these strategic groups. This would help us to find the linkage between strategy groups and performance in the Indian banking sector. Finally, we attempt to identify how efficiency is linked to profitability and what strategic dimensions for future planning can be obtained from the efficiency-profitability matrix.

In this paper, for measuring efficiency of the banks we use non-parametric technique of data envelopment analysis and for identifying strategic groups we use a relatively new multivariate analysis method called Co-plot, which is a multicriteria graphical display method. This can not only identify the different strategic groups, but also a correlation among the different attributes based on which the groupings are made.

The paper is structured as follows: first we give a brief introduction to Indian banking sector followed by a methodology section which gives a brief discussion on DEA with some reference of its application to study banking efficiency and Co-plot method with reference to different past studies which have used this method 
as a tool for multi-criteria grouping. After that, we discuss the data and the performance model used; and in the next section we discuss the results obtained in our study. Conclusions and its implications are discussed in the last section.

\section{AN OVERVIEW OF THE INDIAN BANKING SECTOR}

Prior to 1969, all banks except the State Bank of India and its seven associate banks were privately owned. The Indian policy makers felt that for success of a planned economy and to undertake proper credit planning, it is essential that the control of the banks do not remain with a few private players. By the Nationalization Act of 1969, fourteen largest privately owned banks were nationalized. In 1980, using the same act, six more privately owned banks were taken over by the government (Sarkar, 1999). The main goals of the nationalization process were: (i) to break the monopsony control of the large business houses over the banking system (ii) to spread banking services to the rural areas and (iii) to mobilize funds for the priority sectors like agriculture, small scale enterprises, export sector, etc. (Bhattacharya, 1997). With excessive focus on social obligations, branch network expansion process, and priority sector lending activities, the objective of spreading banking activities to the masses was achieved but it took a heavy toll on the profitability and efficiency of the Indian banks. The rates of return went down, capital base got eroded and customer service hit the lowest level. Beginning in 1985, Reserve Bank of India (RBI), the central bank of the country initiated gradual deregulation of the banking sector so that scarce investible resources are put to more productive use and it culminated to the fundamental banking sector reforms with the acceptance of the Narasimham Committee report in 1992. With gradual reduction of the cash reserve ratio (CRR) and statutory liquidity ratio (SLR), the banks got more investible money, interest rates on the deposits were made free, branching policy were no longer dictated by the social obligations of serving the masses but more by economic viability, and removal of restrictions on the credit allocations gave the individual banks much more flexibility to design their growth strategies. To increase competitiveness among individual banks, the government allowed entry of new private and foreign banks and the nationalized banks were allowed to approach the capital market for fresh funds. To improve the financial soundness of the banks and their borrowing credibility from the market, the government initiated the internationally accepted capital adequacy norms of $8 \%$ as per the Basle Accord and new norms of income recognition and asset classification were introduced (Narasimham Committee, 1991). 
The nationalized banks had a setback in terms of profitability in the initial period of reforms mostly because of the stringent requirements of asset classification and income recognition norms. During 1995-96, most of the public banks started showing distinct sign of financial health improvements. To transform the Indian banking system from asset management to a more generalized framework of assetliability management, to help Indian banks to operate against the new players in the deregulated market and to encourage improvement of customer service through appropriate use of technology, the government appointed the second Narasimham Committee in 1997.

Thus, Indian banking as of today is at a critical juncture. It is essential for the banks to understand the growing interdependence of the various market segments, to develop necessary expertise through a continuous process of planning and organizing, and to restructure themselves to face very stiff competition from the global and domestic private players operating in the market. The government has laid down the foundation for an efficient and well functioning financial system. Now the public banks would surge forward towards greater autonomy with more accountability (Rangarajan, 1996).

\section{METHODOLOGY}

In order to classify the twenty-seven public sector banks operating in India, we employed a graphical representation technique called Co-plot (Raveh, 2000 (a)), which takes into account various key financial ratios used traditionally to measure performance of banks and uses them to identify groups among these banks of various sizes. In the second stage, we measured efficiency of the Indian public banks using the non-parametric method of Data Envelopment Analysis (DEA) developed by Charnes et al. (1978).

\subsection{Co-plot graphical display}

The traditional multivariate statistical methods like principal component analysis, multi-dimensional scaling or cluster analysis analyse only the attributes (strategy variables) on which groupings are made or the observations (the units under consideration) separately. The Multi-Criteria Decision Making (MCDM) method of Co-plot considers all the attributes as well as the observations simultaneously to obtain a two-dimensional plot, which gives the location of each unit corresponding to its measuring variables. Here, two graphs are superimposed sequentially; the first one maps the closely located units and the second one maps 
the similar variables represented with arrows [detailed discussion of Co-plot method is given in Raveh (2000a and 2000b)]. Thus, Co-plot is an exploratory tool, which graphically represents:

(1) correlation among the attributes using which the groupings are made

(2) correlation among the units under observation

(3) mutual relationship among the units and their measuring attributes

Co-plot has been used as an exploratory tool for graphical display in several studies. Giladi, Spector and Raveh (1996) used the method of Co-plot to analyse performance of computers. Lipshitz and Raveh (1998) used Co-plot for analysing socioeconomic differences among localities. Segev, Raveh and Farjoun (1999) have used Co-plot to identify conceptual maps of leading MBA schools in the United States. Raveh (2000a) analysed performance of Greek banks and Raveh (2000b) showed the usefulness of Co-plot to analyse location problems and identify car selection criteria (see appendix 2 for details of the methodology).

\subsection{Data Envelopment Analysis (DEA)}

This is a linear programming technique for measuring relative efficiency for a set of homogeneous decision-making units (DMUs) in converting multiple inputs (resources) to produce multiple outputs (performances). It can identify a set of efficient or best practice units for which no other decision making units or linear combination of units has as much or more of every output (given inputs) or little or less of every input (given outputs). For inefficient DMUs, DEA can measure the slacks in each of the input and output variables and also derive a reference group of efficient units with which they can be directly compared (Cooper, Seiford and Tone, 1999). Since, the pioneering work by Charnes, Cooper and Rhodes (1978), DEA has been extensively applied to study efficiency of homogeneous units like banks and branches of individual banks (Athanassopoulos, 2000), educational institutions (Sarrico and Dyson, 2000), hospitals (Harris et al, 2000), police force (Thanassoulis, 1995) etc.

Data envelopment analysis has been extensively used to study performance of banking sector both for banks as a whole and for branches of individual banks in the last decade. In the literature, two types of approaches have been used by the researchers: production approach where a bank uses labour, capital, space etc to service accounts reflected by transactions like taking deposits, processing loans, insurance applications etc. This approach was used by Vassiloglou and Giokas (1990) for Greek banks, Schaffnit, Rosen and Paradi (1997) to benchmark Canadian banks, Soteriou and Zenios (1999) to study branches of a Cyprus bank etc. The 
second approach that has been used is intermediation approach where a bank is considered to be an intermediary collecting funds in form of deposits and intermediating them to loans and other income earning activities. This was used in many studies like Barr, Seiford and Siems (1994) to assess the managerial efficiency of individual banks and forecast their failure and Athanassopoulos (1995) to study Greek bank branches.

\section{DATA}

Reserve Bank of India, the central bank of the country, publishes a report called "Trends and Progress of Banking in India". This is an annual report, which provides a rich source of data on the operations of all the commercial banks in the country. This report contains compiled information on the financial details from the balance sheet and the profit and loss statement of all the individual banks and also according to their groups based on their ownership like public, private and foreign banks operating in India. It also contains information on the performance ratios as prescribed by the central bank and achieved by the individual banks in the country. The data given here are all statutorily audited and are public information. We took the required data from such an annual report for the financial year 1997-98 on the performance ratios and the financial details as on March 31 $1^{\text {st }}$, 1998 for all the twenty-seven public sector banks of the country (see appendix 1 for the list of banks under study).

In order to build a performance model for the Indian commercial banks, we need to examine the objective of the Indian banks particularly after the financial liberalization era, which began in the year 1991. During the bank nationalization spree in the late sixties and in the early eighties, the entire objective of the Government of India was to spread banking industry to 'touch the lives of millions'. The development indicators were considered as total deposits mobilized, credit disbursed, per capita deposits, per capita credit, population served per bank and the share of the rural branches. The excessive focus on the social obligations at the expense of profitability led to erosion of capital base, very low rate of return, mammoth accrual of non-performing assets and extremely poor customer service (Sarkar, 1999). To overcome these drawbacks in the Indian banking system, the government initiated deregulation of the financial market with opening up the market to private banks. To succeed in this competitive market, the Indian commercial banks have changed their focus to more market-driven performance yardsticks like asset quality, profitability and efficiency. These are the key areas in 
which a public sector bank in India is now required to perform and excel (Trend and Progress in Banking, 1997-98).

Under the Basle Accord, the capital of a bank comprises shareholder's equity, which is the Tier I capital; and undisclosed reserves, revaluation reserves, general loan provisions and subordinated debt as the Tier II capital. According to this accord, any well-capitalized bank in the world should maintain a minimum capital - risk weighted ratio of $8 \%$. Capital-risk weighted ratio, also called capital adequacy ratio (CAR), is defined as the ratio of total capital to risk weighted assets. Riskiness of bank portfolio is an important issue and CAR has been made mandatory by the central bank for any individual bank to open branches or approach the capital market for raising funds. So it is important to find the impact of asset quality as measured by the CAR in our model. When the nationalized banks were on a lending spree to fulfill their social obligations, the banks have rolled into the situation of bad debts with huge accumulation of non-performing assets. Lack of adequate credit appraisal skills, on-site and off-site monitoring and poor supervision of the bank-assisted projects particularly in the priority sector like agriculture have caused to generate huge non-performing assets, which is of very serious concern to any banker in the country. As a measure of asset quality it is imperative to also include the ratio of the net non-performing asset to the net advance in our model.

The concept of profitability was almost absent in the pre-reform era in the Indian banking system. The entire banking industry was guided by social objectives rather than any economic viability. With the onset of financial reforms, the policy makers laid increasing emphasis on profitability of individual banks as an important benchmark not only for their continued sustenance but also to approach the equity market with a healthy looking balance sheet. We have included return on asset, ratio of operating profit to average working funds and net profit to net worth as standard banking measures of profitability in our model. One of the biggest obstacles, which the Indian public sector banks are facing today, is overmanning. In 1995-96, the ratio of officers to assets in public banks was five times that of a foreign bank (Sarkar, 1999). The ratio of wages and salaries to the total operating expense was also much higher for a public sector bank. The main reason for this overmanning was indiscriminate employment of under-qualified people to fulfill the social obligations in the pre-liberalization era. The overwhelming control of the trade unions in the operations of the banks also created a bottleneck and has almost thwarted the attempt of the public sector banks to remain competitive in the face of the onslaught from the better performing foreign and domestic private sector banks. To understand, how each public bank is performing inspite of the 
excess labour problem, we have included the ratio of profit generated per employee as a measure of profitability in our model.

To remain competitive in the industry, the public banks are undertaking huge investments in technology up-gradation and are trying to reduce the operating cost by making the decision process more streamlined. Thus, the issue of efficiency in operations and revenue generation is of utmost interest to the policy makers in the Indian banking industry. We have considered two ratios: operating expense to the net profit earned to measure the operating efficiency of individual banks and income from both interest and non-interest sources to the average working funds expended as the measure of revenue generating efficiency.

Thus, we considered eight financial ratios to measure the three broad strategic performance areas, viz., asset quality, profitability and efficiency, in an effort to categorize the twenty-seven public sector banks into different strategic groups in the first phase of our study.

Asset quality $\Rightarrow$ capital adequacy ratio; net non-performing asset/ net advance Profitability $\Rightarrow$ return on asset; operating profit/ average working fund; net profit/ net worth; profit/ employee

Efficiency $\quad \Rightarrow$ operating expense/ net profit; income (interest and non-interest)/ average working fund

There have been two approaches discussed in literature to the choice of how to measure flow of services as provided by a banking institution. In the 'intermediation' approach, a bank is considered to be using interest expenses and operating expenses in the process of revenue generating services for its customers and all the variables are measured in terms of its monetary value. This approach is particularly used when efficiency of the bank as a whole is measured rather than comparing its individual branches. In the alternative 'production' approach, a bank is considered to be performing transactions and processing documents like loan applications where the output is measured by the number and the type of transactions. This method is more applicable for measuring performance of branches of a banking institution (Berger and Humphrey, 1997). In India, commercial banks are considered to act as 'intermediary' between investors who are depositing their money with the banks in exchange of monetary returns; and the borrowers who are approaching the banks for funds. Thus, in our study, we have used the intermediation approach where the objective of the bank is to mobilize deposit for prudent lending and investment. 
Since nationalization, the major objective of the banking sector was deposit mobilization. Performance of the public sector banks has been always impressive in this regard. Growth in the post reform period also followed the earlier trend. The central bank has always carefully nurtured its monetary and credit policy by deregulating the deposit rates, lowering of the cash reserve ratio (CRR) to positively influence the rate of deposit mobilization. Recent spurt from the different types of non-resident Indians (NRI) accounts have further helped in a net inflow in the deposit accounts of all the public sector banks. To mobilize the fund from the investors, a bank has to incur a substantial sum of money in form of operating expense and also interest expense in the form of inter-bank borrowings, interest on the deposits taken etc. We took the total expense as the sum of all the individual expenditures incurred by a bank in order to mobilize the funds from its investors. Thus, in the second phase of our study, for calculating the efficiency of the twentyseven Indian public sector banks using the DEA model, we took deposit and total expenditure as our inputs. The banks had always the motivation to lend this money to suitable borrowers in the form of directed lending and investment. Thus, as outputs in our efficiency calculation model, we considered advances (comprising of bills purchased and discounted, credits, overdrafts, and loans) and investments (government securities, shares, debentures and bonds), which a bank is providing to their clients. The choice of these input and output variables have been supported by earlier studies on efficiency of Indian banking system using the method of DEA by Bhattacharya et al. (1997) and Saha and Ravisankar (2000). All the data were in terms of Indian rupees in million (see Table 1 for the list of variables chosen in the DEA efficiency model) although DEA can handle variables having different units of measurement.

\begin{tabular}{|c|c|}
\hline Inputs & Outputs \\
\hline Deposit & Advance \\
\hline Total expense & Investment \\
\hline
\end{tabular}

Table 1. Financial Variables Considered in the DEA Efficiency Model

\section{RESULTS AND DISCUSSIONS}

\subsection{Strategic Group Identification}

We started with the 8 key financial ratios describing the three dimensions of asset quality, profitability and efficiency as discussed earlier as the key performance indicators of the Indian public sector banks. These ratios have been used by the 
central bank to measure performance changes of the Indian public sector banks annually. We employed principal component analysis (PCA) method to identify the most important ones among them describing the three performance dimensions. This method of identification of key financial ratios that best describe the financial performance of a bank using PCA has been used by Zopounidis (1995) to group Greek banks and also by Serrano Cinca (1998) to categorize Spanish saving banks. Factor analysis was used with varimax rotation to group the eight ratios, and three factors, with eigen value greater than 1 and explaining $84.89 \%$ of the cumulative variance (analysis was carried out using SPSS version 7.5.2), were obtained. Due to very high correlation between capital adequacy ratio and return on asset (0.763), between operating profit to average working fund and net profit to net worth $(0.827)$, and between operating profit to average working fund and return on asset (0.728), we dropped capital adequacy ratio and operating profit/ average working fund from our reference set.

\begin{tabular}{|l|r|r|r|}
\hline & \multicolumn{3}{|c|}{ Component } \\
\hline & 1 & 2 & 3 \\
\hline Net NPA/ net advance & -0.325 & -0.007 & $\mathbf{0 . 9 4 1}$ \\
\hline Return on Asset & $\mathbf{0 . 8 6 2}$ & -0.008 & -0.245 \\
\hline Net profit/ net worth & $\mathbf{0 . 8 6 7}$ & 0.009 & -0.23 \\
\hline Profit/ employee & $\mathbf{0 . 9 0 9}$ & -0.103 & -0.218 \\
\hline Operating expenses/ net profit & -0.157 & $\mathbf{0 . 9 1 5}$ & -0.002 \\
\hline Income/ average working fund & 0.399 & $\mathbf{0 . 5 9 5}$ & -0.121 \\
\hline
\end{tabular}

Table 2. Results of Principal Component Analysis with Varimax Rotation

The three factors, which we had hypothesized, were confirmed by the PCA analysis. They are: asset quality measured by net non-performing asset/net advance; profitability comprising of return on asset, net profit/ net worth and profit/ employee; and efficiency measured with income (interest and non-interest)/ average working fund and operating expense/ net profit.

All the twenty-seven public sector banks operating in the country were subjected to Co-plot analysis with these six financial ratio figures. From the results of the co-plot analysis, the correlation coefficient of operating expense/ net profit ratio with the rest of the ratios turned out to be quite low (0.66). Thus, it was discarded and the 27 banks were again subjected to the Co-plot analysis with the remaining five financial ratios as their differentiating attributes. Thus, the set of key financial ratios finally used in our analysis were (Table 3 gives a summary of the variables used): 
r1: return on asset (profitability)

r2: net profit/ net worth (profitability)

r3: profit per employee (profitability)

r4: income (interest and non-interest)/ average working fund (efficiency)

r5: net non-performing asset/ net advance (asset quality)

\begin{tabular}{|l|r|r|r|r|r|}
\hline Variables & Mean & Median & SD & Min & Max \\
\hline Return on asset & 0.806 & 0.828 & 0.539 & -0.57 & 2.43 \\
\hline Net profit/ Net worth & 0.141 & 0.167 & 0.923 & -0.108 & 0.289 \\
\hline Profit per employee & 0.711 & 0.685 & 0.466 & -0.03 & 1.73 \\
\hline Income/ Average working fund & 11.543 & 11.556 & 0.854 & 0.854 & 13.04 \\
\hline Net NPA/ Net advance & 9.131 & 7.970 & 4.398 & 2.92 & 26.01 \\
\hline Expense & 212735.2 & 128502 & 273326.9 & 38893 & 1519410 \\
\hline Deposit & 1969365 & 1254779 & 2397858 & 336878 & 13109132 \\
\hline Investment & 841121.8 & 620979 & 986498.3 & 149850 & 5498224 \\
\hline Advance & 962601.9 & 537889 & 1353468 & 190165 & 7423733 \\
\hline
\end{tabular}

Table 3. Summary Statistics for the Data Used for Strategic Grouping and Efficiency Measurement

Five strategic groups were identified with coefficient of alienation $\mathrm{q}=0.1$, which was quite satisfactory with average correlation among the five attributes 0.874. So, the goodness of fit measures was satisfied both for the observations (banks) and the attributes (financial ratios). The five financial ratios were represented using five arrows according to their degree of correlation among them, the higher the value more is the closeness. The cosines of the angles between these arrows were proportional to the correlations between the five financial ratios. An arrow representing a certain variable tends to rise toward the higher-thanaverage values. All the banks located towards the direction of the arrow have values, which are higher than the average. Figure 1 gives the composite picture of the strategic groupings for the twenty-seven public sector banks using five performance ratios. The groups were formed using Guttman's smallest space analysis, which is the graphical representation of pairwise inter-relationship of the units under study (for detailed methodology see appendix 2). This particular technique has been used earlier to group 16 Greek banks (Raveh, 2000). The banks are partially ordered from left to right according to their increased performance. The direction of performance is same as the three profitability measures. The asset quality attribute is opposite to the performance direction. This signifies, banks, 
which are risk averse, have a better asset quality in terms of more secured loans but may lose on its earning potential without adding much to the performance features of the banks. The attribute of income/average working funds, which denotes the operational efficiency of a bank, is almost orthogonal to the profitability direction, which shows that they contribute less to the earning ability of the banks.

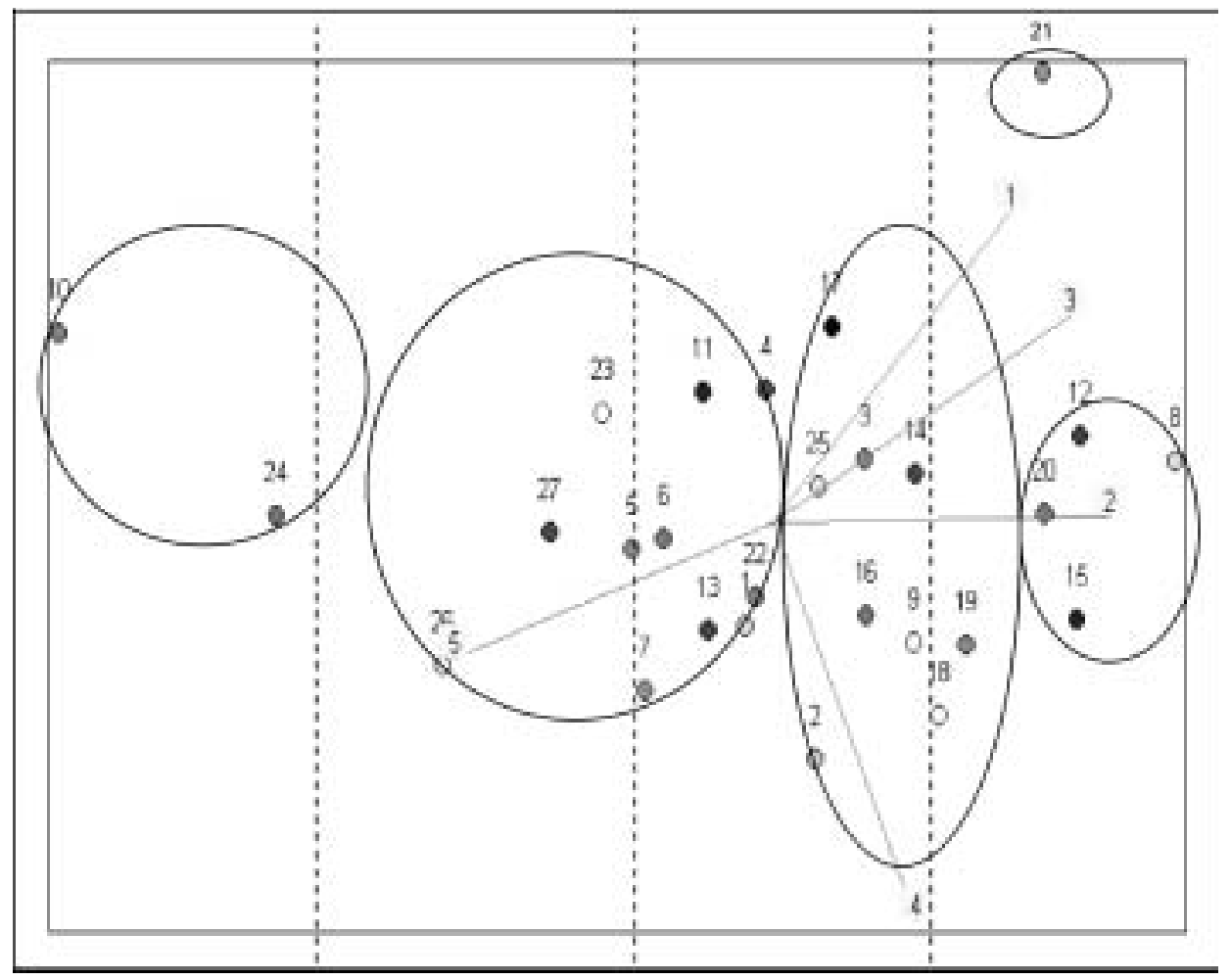

Figure 1. Strategic Grouping of the Indian Public Sector Banks Using Financial Performance Ratios.

Attributes: 1. Return on Asset 2. Net Profit/ Net Worth 3. Profit/ Employee (all denoting profitability). 4. Income/ Average Working Fund (efficiency) 5. NPA/ Net Advance (asset quality)

Thus, grouping of the twenty-seven banks (refer to Appendix 1 for the list of banks under study) into five strategic groups according to the five financial ratios gave us the following:

- Group 1:Bank \# 8,12,15,20: The best performing group, having the most profitability with high operational efficiency but low on asset quality. So these banks are high-risk takers and good fund managers. It shows how smaller and medium sized banks have paid attention to market segmentation carving out their niche. These banks have always termed to one of the best in terms of 
delivering customer service competing with the best private and foreign players in non-fund business like advisory services and retail service products.

- Group 2: Bank \# 21: A group by itself exhibiting high performance in terms of profitability and operational efficiency but low on asset quality. It is one of the best performing associated bank belonging to the State Bank of India (SBI), which is the largest bank of the country. Even, in terms of return on asset, it is far superior than any of the other six associated banks belonging to SBI.

- Group 3: Bank \# 2,3,9,14,16,17,18,19,25: Medium on profitability but has very high operational efficiency with good asset structure. These banks are all medium to large sized banks, including SBI and some of its associates, with high return on equity and return on investment figures.

- Group 4: Bank \# 1,4,5,6,7,11,13,22,23,26,27: Medium in profitability and also in operational efficiency with less than the average asset structure. Banks 1,4,22 are located within a relatively short circle of radii from the center of gravity. They constitute the typical or the average banks with average value on all the five performance attributes.

- Group 5: Bank \# 10,24: Extremely low in profitability and low degree of operational effectiveness but has good asset quality. Both these banks were loss-making banks with negative returns on assets. According to the report of the Verma Commission, which was commissioned by Reserve Bank of India (1999), these two particular banks were going bankrupt and needed restructuring. If we go through the financial statements of both these banks, we can see both Indian Bank and UCO Bank have extremely low capital adequacy ratio (CAR) signifying poor asset structure, with high non-performing assets (NPA), which signifies their bad investment decisions.

We also see from the mapping of the banks in this graphical display that Bank \# 1 and 22 (Allahabad Bank and State Bank of Travancore) are very similar according to the five performance parameters we have chosen in this study. In fact, they are closest to the center of gravity and represent 'typical' Indian public sector banks.

Thus, in the first phase of our study, we obtained the strategic grouping of the Indian public sector banks, such that the groups are internally homogeneous and externally heterogeneous based on their financial performance parameters. Position of each bank in this conceptual map shows how it is placed relative to its competitors and also the degree of homogeneity among the performance parameters. Analysis of poor performers by going through their individual financial statements and annual reports reveal they are plagued with overstaffing, low productivity, and 
inefficient training facilities, thus causing low employee morale. With intense competition from both domesticn and international players, rapid innovation of new financial instruments, changing consumer demands and explosive growth in information technology, the way a banking firm used to do business has totally changed. In order to survive and adapt to the changing environment, banking firms need to position themselves with respect to their strategic groups, thus improving perceived service quality and its performance metrics.

\subsection{Strategic Group and Performance Linkage}

Based on Porter (1979), we begin with the following central hypothesis: Performance difference (measured in terms of efficiency and profitability) exists among different strategic groups.

The position of the individual banks on the two-dimensional Co-plot graphical display shows their relative rankings based on their earning ability or profitability measures. Banks are considered to play the role of intermediaries of collecting funds in form of deposits, incurring expense to service transactions and using resources to disburse loans and other income generating activities. In the second stage, we measure the overall performance of a bank in its intermediary activities by its technical efficiency which measures how efficient is a bank in transforming its resources into income generating transactions by applying the non-parametric method of DEA. We have used output-oriented variable-returns-to-scale BCC model (Banker, Charnes and Cooper, 1984). We considered a variable-return-toscale model as the banks are of different sizes and not operating at an optimal scale due to imperfect competition and resource constraints, and an output-oriented model as we assumed that the banks were trying to utilise their given resources to deliver the maximum outputs (see appendix 3 for detailed discussion of the model). As a measure of profitability index, we calculated net profit divided by the total expense incurred by the banks. This index was scale independent and size independent, so bigger banks do not get undue advantage for their size. Nine out of the twenty-seven banks turned out to be BCC efficient (efficiency =1), with average efficiency equal to 0.975 and minimum efficiency to be 0.864 (see figure 2 for the frequency distribution of efficiency of the banks).

From the output slacks obtained from the output oriented BCC model, we calculated the improvement potential for individual banks (see figure 3 ) in terms of their two outputs of investment and advance. The efficient banks have optimized 
their input resources in terms of generating outputs; only the inefficient banks due to their underutilization of resources have not reached that optimal stage of output generation mechanism.

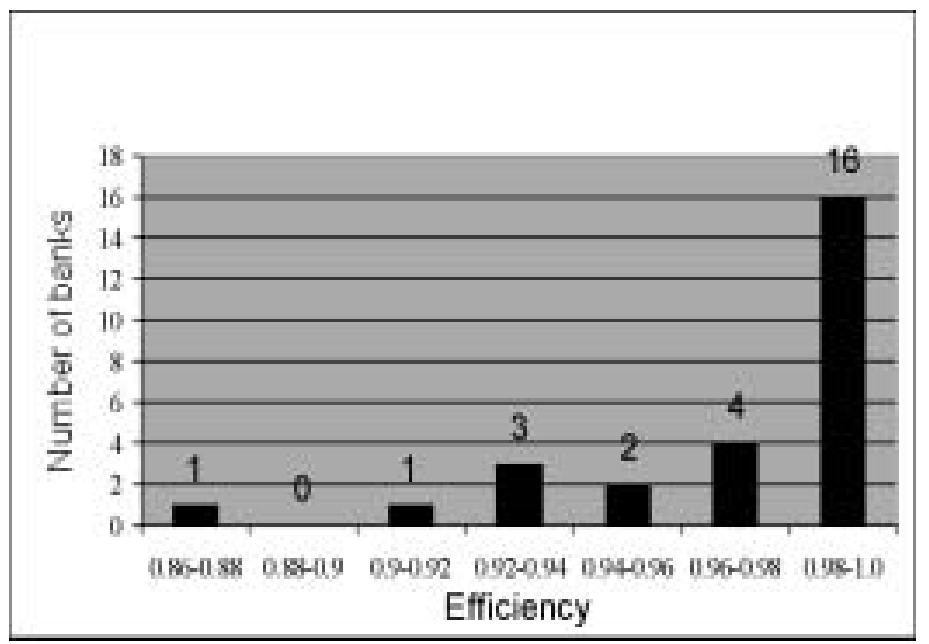

Figure 2. Frequency Distribution of BCC Efficiency for Indian Public Sector Banks

Policy makers of the Indian banking system can get lot of insights about the inherent technical inefficiencies present in the operation of the individual banks and necessary guidelines can be developed to improve their efficiency and thus profitability to survive in this liberalized banking scenario.

A MANOVA test was conducted on the six strategic groups to see whether the groups really differed on performance measures of efficiency and profitability (Cooley and Lohnes, 1971). From the equality of covariance test, the observed value of Box's M is 1.47 and $F$ statistic is 0.123 with degree of freedom $(9,1100)$ at 0.05 level of significance. Dispersion across the groups was not found to be significant. From testing the equality of the group centroids, the observed value of Wilk's lambda is 0.295 with Rao's F statistic as 4.489 with degree of freedom $(6,32)$ at 0.05 level of significance. Hence, the mean vectors are not the same after comparing it with the table of percentage point of $\mathrm{F}$ distribution. While calculating dispersion, two groups (Group 2 and 5) were not considered as they had only one unit, which is exceptional in terms of its size, performance and level of operation. On the other hand, all the six groups were considered while calculating for group centroids. Thus, we find that performance across strategic groups varies significantly and it can be used as an effective discriminator for competitive positioning. 


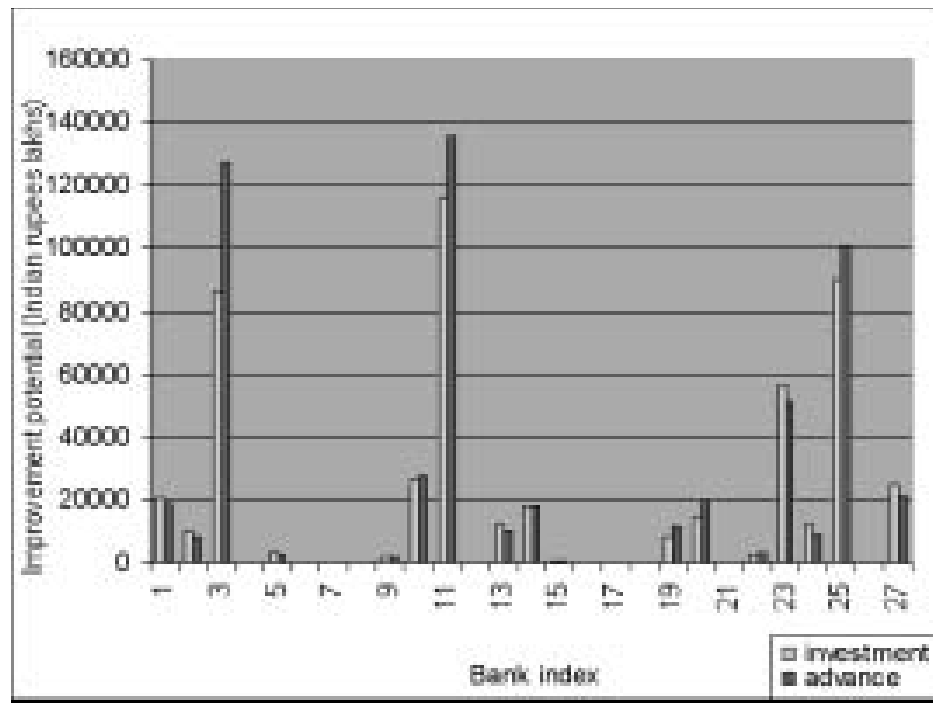

Figure 3. Improvement Potential in the Performance Outputs for the Indian Public Sector Banks

\subsection{Efficiency - Profitability Linkage}

We calculated the efficiency of the banks in converting their resources into earning ability using DEA and developed a scale and size independent profitability measure. To analyse whether technical efficiency leads to better profitability, we used the efficiency-profitability matrix originally proposed by Boussofiane, Dyson and Thanassoulis (1991). Soteriou and Zenios (1999) and Camanho and Dyson (1999) used this approach to benchmark Cyprus and Portuguese banks.

The efficiency and the profitability index for the 27 banks were plotted in a two dimensional space (see figure 4). The matrix was divided into four quadrants where the boundary positions were subjective (Camanho and Dyson, 1999). Some banks were high on efficiency scored medium but low in terms of profitability. The best performers (Group 1 from our Co-plot analysis) belonged to the 'I' quadrant. It is the benchmark set with high efficiency and profitability, which the other banks can take a cue to decide on their business policy. Most of the high performing banks (Group 3 from our Co-plot analysis) fell in the 'I' and in the 'IV' quadrant. They were the banks, which are operating with high efficiency but there is scope for improvement in their profit potential. These banks were quite high in their earning power but why their profitability was low should be analysed. Probably, because of the unfavourable environmental situations, like wrong product portfolio or market positioning. Bank 26 (Indian Bank) came to be an outlier in 


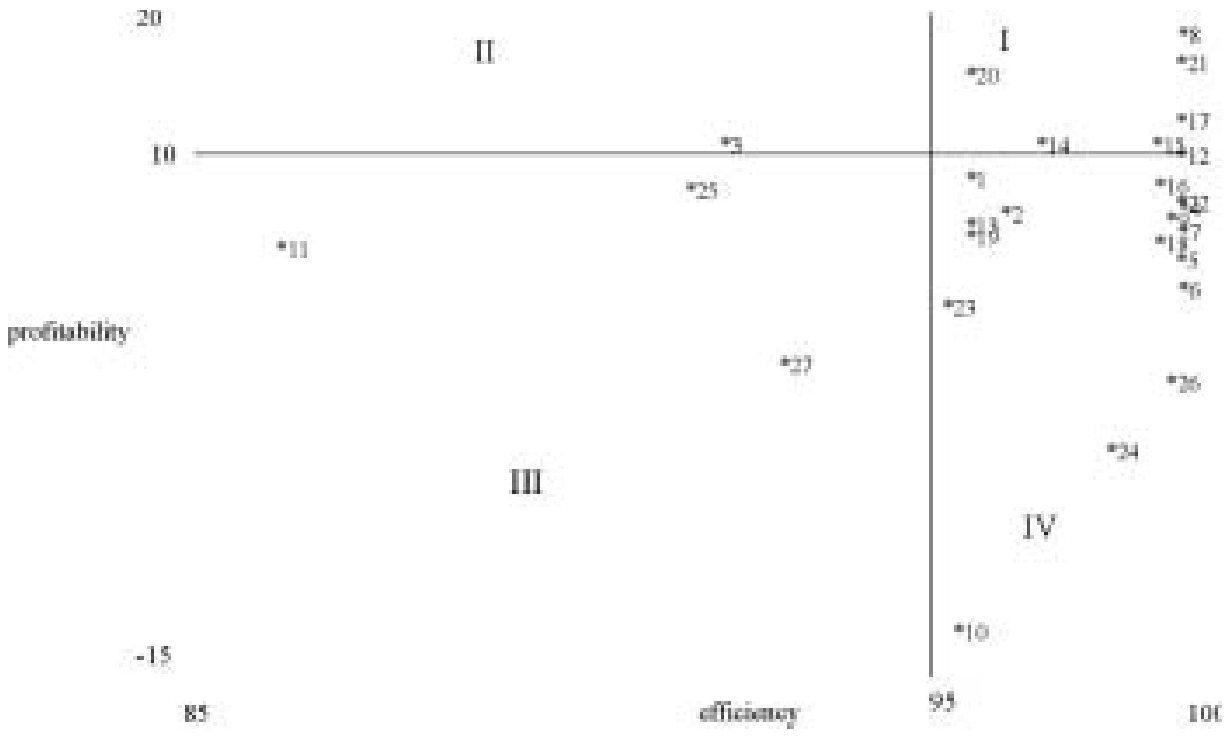

Figure 4. Efficiency-Profitability Matrix for the Indian Public Sector Banks

the lot with high efficiency but with extremely low profitability. Indian Bank was facing the problem of very low CAR with extremely high NPA and operating expense, which was mostly due to enormous unproductive staff body, which has caused its low profitability. Banks located in the 'III' quadrant should seriously re-think about their long-term business policy, as they were low in both efficiency and profitability. They should try to emulate banks in other quadrants for their policy decisions provided they enjoy similar business environment. So, either they are facing unfavourable environment or have poor managerial skills or both. All the banks, which came out to be poor performers from our Co-plot analysis, were grouped in either 'III' or the 'IV' quadrant. Banks in 'II' quadrant are favourably placed with good profitability but poor efficiency. They have the potential for improvement by implementing better management skills. There is a significant positive relationship between efficiency and profitability and such matrix can be used to identify benchmarks and identify the set of banks for which improvement can be made with very little restructuring effort.

\section{CONCLUSIONS}

This study dealt with identifying strategic groups within the 27 Indian public sector banks using their financial parameters. Principal component analysis was used to 
identify the key ratios measuring profitability; efficiency and asset quality, and the banks were grouped into five groups using the graphical display method of Co-plot. To study the linkage between strategic groups and their performance measures, we calculated their overall technical efficiencies using the DEA model and developed a size-independent profitability index. From the slacks in terms of underproduction of outputs, we calculated the improvement potential that can be achieved by better utilization of existing resources for each individual bank. The efficiency-profitability matrix indicated that there is a positive association between the two.

Strategic group identified with Co-plot display proved to be an excellent discriminator among industry performers. Since, we found a conclusive and positive association between strategic groupings and firm performance as measured by their overall technical efficiency score which is contrary to earlier studies, this can provide a new dimension to strategic group-firm performance linkage studies. Predicting firm performance from membership in a particular strategic group can emerge as an area of future research. Although this study has ignored the effects of group changes over time, a subject of future research attention could be a study of the stability in group membership over a longer time frame. Customer responses on their satisfaction level can be included to get the competitive positioning of individual banks in their customers' mindset. To get a better understanding of the relationship between efficiency and profitability, individual banks should be studied in detail to find out the discriminatory factors leading to high efficiency but low profitability. This study can provide guidelines to Indian banks to ascertain their position in the target market by knowing their competitors better, take long term strategic focus to utilise their own resources and offer a better customer service.

Analysis of poor-performing banks reveals they are plagued with overstaffing, low productivity and inefficient training facilities, causing low employee morale. Such type of performance analysis and identification of strategic grouping can help individual banks to benchmark themselves with respect to competition, compete with better performers, develop their own business strategies and strive for excellence. The study has important implications, such as guiding government policy regarding deregulation and mergers. The study can also help banks to take appropriate decisions on strategic marketing, restructuring, branch closures or downsizing.

Like any other study, this research is also not without its limitations. The variables presented should be regarded as examples rather than universally accepted measures of bank performance. The variables used are all objective measures, 
which influence perceptual variables like customer satisfaction or service quality. However, due to methodological limitations of DEA, perceptual variables were not directly included in the study. Strategic groups are generated here using performance indicators. In a sense, the groups are generated on the choice of performance ratios and it is assumed that the strategies adopted by the banks are reflected in these financial ratios. Individual banks can be chosen from a better and a poor performing strategic groups and their inherent difference in term of long term focus, strategic vision, operating efficiency can be studied in much more detail giving further insight to the area of banking supervision. The entire grouping was obtained using only one year of financial data but it can be done on a yearly basis to see the overall change in the performance across different groups and how each individual bank is gearing their yearly strategies to overcome the competition. Moreover, we used only five performance parameters to group 27 banks, which make the data set quite small. The initial eight ratios selected by us for this study have been used by the central bank to understand performance of the public banks in India, so we adopted the same financial ratios. This is unlike some of the earlier studies, e.g., Serrano Cinca (1998) used as many as 30 financial ratios to determine strategic positioning for 56 Spanish banks.

However, on the whole, this paper makes an important contribution both conceptually and methodologically in trying to uncover the linkages between strategic groups and performance of banks using a combination of Data Envelopment Analysis and Co-plot graphical display methods. 


\section{APPENDIX 1. Indian public sector banks under study}

\begin{tabular}{|l|l|l|}
\hline 1. Allahabad Bank & 2. Andhra Bank & 3. Bank of Baroda \\
\hline 4. Bank of India & 5. Bank of Maharashtra & 6. Canara Bank \\
\hline 7. Central Bank of India & 8. Corporation Bank & 9. Dena Bank \\
\hline 10. Indian Bank & 11. Indian Overseas Bank & 12.Oriental Bank of Commerce \\
\hline 13. Punjab and Sind Bank & 14. Punjab National Bank & 15.State Bank of Bikaner \& Jaipur \\
\hline 16. State Bank of Hyderabad & 17. State Bank of India & 18. State Bank of Indore \\
\hline 19. State Bank of Mysore & 20. State Bank of Patiala & 21. State Bank of Saurashtra \\
\hline 22. State Bank of Travancore & 23. Syndicate Bank & 24. UCO Bank \\
\hline 25. Union Bank of India & 26. United Bank of India & 27. Vijaya Bank \\
\hline
\end{tabular}

\section{APPENDIX 2. Co-plot graphical display - A brief overview}

It is a graphical display method to visualize data matrices of the form $Y_{n \times p}$ where, $\mathrm{n}$ represents the observations exhibited in the plot by $\mathrm{n}$ points and $\mathrm{p}$ represents the variables exhibited by $\mathrm{p}$ arrows relative to the same axes and origin located in a two dimensional plot. It is a bi-plot diagram with two graphs superimposed sequentially, where the first graph maps the $\mathrm{n}$ observations and the second graph portrays the $\mathrm{p}$ variables and hence the name. It has four stages:

\section{Stage 1}

The elements of the data matrix $Y_{n \times p}$ are first normalized by taking the deviation from the column mean $\left(\bar{Y}_{. j}\right)$ and dividing it by the standard deviation $\left(S_{j}\right)$.

$Z_{i j}=\left(Y_{i j}-\bar{Y}_{. j}\right) / S_{j}$

Stage 2

Dissimilarities $\left(S_{i k} \geq 0\right)$ are calculated between each pair of observations with the sum of the absolute deviations as the measure for it.

$$
S_{i k}=\sum_{j=1}^{p}\left|Z_{i j}-Z_{k j}\right| \geq 0,(1 \leq i, k \leq n)
$$




\section{Stage 3}

The matrix $S_{i k}$ is mapped in a Euclidean space with 2 dimensions where the $\mathrm{n}$ observations represented by $\mathrm{n}$ points using the Guttman's smallest space analysis as a form of nonmetric multidimensional technique. It gives a graphic representation of the pairwise interrelationship between the $\mathrm{n}$ observations using the coefficient of alienation $\Theta$ as the measure for goodness of fit. The value of the coefficient less than 0.15 is considered to be satisfactory.

\section{Stage 4}

The $p$ variables are mapped onto the Euclidean space by $p$ arrows. Cosines of the angles between these arrows are proportional to the correlations between the variables. So, arrows associated with highly correlated variables point in the same direction. The magnitude of the p maximal correlations measures the goodness of fit of the $\mathrm{p}$ regressions. Higher is the correlation, the better is the arrow representations of the variables and those having low correlations should be eliminated.

\section{APPENDIX 3. The DEA Model used}

We used the output-oriented BCC model, which allows variable returns to scale (Banker, Charnes and Cooper, 1984). The mathematical formulation is as follows:

$\max \gamma_{0}+\varepsilon\left(\sum_{i=1}^{m} s_{i}^{-}+\sum_{r=1}^{s} s_{r}^{+}\right)$

s.t. $\sum_{j=1}^{n} \lambda_{j} x_{i j}+s_{i}^{-}=x_{i 0} \quad i=1,2, \ldots, m$

$\sum_{j=1}^{n} \lambda_{j} y_{r j}-s_{r}^{+}=\gamma_{0} y_{r 0} \quad r=1,2, \ldots, s$

$\sum_{j=1}^{n} \lambda_{j}=1$

$\lambda_{j}, s_{i}^{-}, s_{r}^{+} \geq 0$ 
where $\mathrm{x}_{\mathrm{ij}}$ and $\mathrm{y}_{\mathrm{rj}}$ are the amount of the $i$ th input consumed and the amount of $r$ th output produced by the $j$ th bank with each bank consuming using $m$ different inputs to produce $s$ different outputs. In our case, we had two inputs $(\mathrm{m}=2)$ and two outputs $(\mathrm{s}=2)$ for twenty-seven banks $(\mathrm{n}=27)$. Here, $\gamma_{0}$ is the optimal value of efficiency. A bank is said to be BCC efficient if $\gamma_{0}=1$ and has no input slack $\left(s_{i}^{-}\right)$ and output slack $\left(s_{r}^{+}\right)$, otherwise, it is BCC inefficient.

\section{REFERENCES}

Aigner, D, C.A.K. Lovell and P. Schmidt (1977): Formulation and Estimation of Stochastic Frontier Production Function Models. Journal of Econometrics 6: 21-37.

Athanassopoulos, A.D. (1995): Multivariate and Frontier Analysis for Assessing the Market and Cost Efficiency of Large Scale Bank Branch Networks. Working paper, University of Warwick, Coventry, U.K.

Athanassopoulos, A.D. (2000): The Use of Data Envelopment Analysis in Banking Institutions: Evidence from Commercial Banks of Greece. Interfaces 30 (2): 81-95.

Banker, R.D., A. Charnes and W.W. Cooper (1984): Some Models for Estimating Technical and Scale Inefficiencies in Data Envelopment Analysis. Management Science 30: 1078-1092.

Barr, R., L.M. Seiford and T. Siems (1994): Forecasting Bank Failure: A NonParametric Approach. Recherches Economiques de Louvain 60: 411-429.

Berger, A.N. and D.B. Humphrey (1997): Efficiency of Financial Institutions: International Survey and Directions for Future Research. European Journal of Operational Research 98 (2): 175-212.

Bhattacharya, A., C.A.K. Lovell and P. Sahay (1997): The Impact of Liberalization on the Productive Efficiency of Indian Commercial Banks. European Journal of Operational Research 98 (2): 332-345.

Boussofiane, A., R.G. Dyson and E. Thanassoulis (1991): Applied Data Envelopment Analysis. European Journal of Operational Research 52 (1): 1-15.

Camanho, A.S. and R.G. Dyson (1999): Efficiency, Size, Benchmarks and Targets for Bank Branches: An Application of Data Envelopment Analysis. The Journal of the Operational Research Society 50: 903-915. 
Charnes, A., W.W. Cooper and E. Rhodes (1978): Measuring the Efficiency of Decision Making Units. European Journal of Operational Research 2: 429-444.

Cool, K.O. and D.E. Schendel (1987): Strategic Group Formation and Performance: The case of U.S. Pharmaceutical Industry, 1963-1982. Management Science 33(9): 1102-1124.

Cooley, W.W. and P.R. Lohnes (1971): Multivariate Data Analysis, John Wiley \& Sons Inc., New York.

Cooper, W.W., L.M. Seiford and K. Tone (1999): Data Envelopment Analysis - A Comprehensive Text with Models, Applications, References, Kluwer Academic Publisher, Holland.

Day, D.L., A.Y. Lewin and H. Li (1995): Strategic Leaders or Strategic Groups: A Longitudinal Data Envelopment Analysis of the U.S. Brewing Industry. European Journal of Operational Research 80 (3): 619-638.

Fiegenbaum, A. and H. Thomas (1990): Strategic Groups and Performance: The U.S. Insurance Industry, 1970-84. Strategic Management Journal 11 (3): 197-215.

Giladi, R., Y. Spector and A. Raveh (1996): Multidimensional Scaling: An Analysis of 1980-1990 Computers. European Journal of Operational Research 95 (2): 439450 .

Giokas, D. (1991): Bank Branch Operating Efficiency: A Comparative Application of DEA and the Loglinear Model, Omega 19 (6): 549-557.

Harris, J., H. Ozgen and Y. Ozcan (2000): Do Mergers Enhance the Performance of Hospital Efficiency. The Journal of the Operational Research Society 51 (7): 801-811.

Hunt, M.S. (1972): Competition in the Major Home Appliance Industry, 19601970. Unpublished Ph.D. dissertation, Harvard University.

Lewis, P. and H. Thomas (1990): The Linkage between Strategy, Strategic Groups, and Performance in the U.K. Retail Grocery Industry. Strategic Management Journal 11: 385-397.

Lipshitz, G. and A. Raveh (1994): Applications of the Co-plot Method in the Study of Socioeconomic Differences among Cities: A basis for Differential Development Policy. Urban Studies 31: 123-135. 
McGee, J. and H. Thomas (1986): Strategic Groups: Theory, Research and Taxonomy. Strategic Management Journal 7 (2): 141-160.

Mehra, A. (1996): Resource and Market Based Determinants of Performance in the U.S. Banking Industry. Strategic Management Journal 17 (4): 307-322.

Narasimham Committee (1991): Report of the Committee on the Financial System, Government of India.

Oral, M. and R. Yolalan (1990): An Empirical Study on Measuring Operating Efficiency and Profitability of Bank Branches. European Journal of Operational Research 46 (3): 282-294.

Porter, M.E. (1979): The Structure Within Industries and Companies' Performance. Review of Economics and Statistics 61 (May): 214-227.

Porter, M.E. (1980): Competitive Strategy, Free Press, New York.

Rangarajan, C. (1996): Banking Sector Reforms: Rationale and Relevance in Rangarajan C. (ed.) Indian Economy: Essays on Money and Finance, UBSPD, New Delhi, India.

Raveh, A. (2000a): The Greek Banking System: Reanalysis of Performance. European Journal of Operational Research 120 (3): 525-534.

Raveh, A. (2000b): Co-plot: A Graphic Display Method for Geometrical Representations of MCDM. European Journal of Operational Research 125 (3): 670-678.

Reserve Bank of India Report (1998): Trends and progress of banking in India 1997-1998, Reserve Bank of India, Mumbai, India.

Reserve Bank of India Report (1999): Trends and progress of banking in India 1998-1999, Reserve Bank of India, Mumbai, India.

Reserve Bank of India Report (2000): Trends and progress of banking in India 1999-2000, Reserve Bank of India, Mumbai, India.

Saha, A., and T.S. Ravisankar (2000): Rating of Indian Commercial Banks: A DEA Approach. European Journal of Operational Research 124 (1): 187-203.

Sarkar, J. (1999): India's Banking Sector: Current Status, Emerging Challenges, and Policy Imperatives in a Globalized Environment in Hanson, J.A. and Kathuria, 
S. (ed.) India: A Financial Sector for the Twenty-first Century, Oxford University Press, India.

Sarrico, C.S. and R.G. Dyson (2000): Using DEA for Planning in U.K. Universities: An Institutional Perspective. The Journal of the Operational Research Society 51 (7): 789-800.

Schaffnit, C., D. Rosen and J.C. Paradi (1997): Best Practice Analysis of Bank Branches: An Application of DEA in a Large Canadian Bank. European Journal of Operational Research 98 (2): 270-290.

Second Narasimham Committee (1997): Committee on Banking Sector Reform. Gazette of India. Ministry of Finance, Government of India.

Segev, E., A. Raveh and M. Farjoun (1999): Conceptual Maps of the Leading MBA Programs in the United States: Core Courses, Concentration Areas, and the Ranking of the School. Strategic Management Journal 20 (6): 549-565.

Seiford, L.M. and Joe Zhu (1999): Profitability and Marketability of the Top 55 U.S. Commercial Banks. Management Science 45 (9): 1270-1288.

Serrano Cinca, C. (1998): From Financial Information to Strategic Groups-a Self Organizing Neural Network Approach. Journal of Forecasting 17: 415-428.

Soteriou, A. and S.A. Zenios (1999): Operations, Quality and Profitability in the Provision of Banking Services. Management Science 45 (9): 1221-1238.

Sudarsanam, P. and R. Taffler (1985): Industrial Classification in U.K. Capital Markets: A Test of Economic Homogeneity. Applied Economics 17: 291-308.

Thanassoulis, E. (1995): Assessing Police Forces in England and Wales Using Data Envelopment Analysis. European Journal of Operational Research 87 (3): 641-658.

Vassiloglou, M. and D. Giokas (1990): A Study of the Relative Efficiency of Bank Branches: An Application of Data Envelopment Analysis. The Journal of the Operational Research Society 41: 591-597.

Verma Committee (1999): Report on Restructuring Public Sector Banks, Reserve Bank of India, Mumbai, India.

Zineldin, M. (1996): Bank Strategic Positioning and some Determinants of Bank Selection. International Journal of Bank Marketing 14 (6): 12-22. 
Zopounidis, C., D.K. Despotis and E. Stavropoulou (1995): Multiattribute Evaluation of Greek Banking Performance. Applied Stochastic Models and Data Analysis 11: 97-107. 